THE EXEMPLARY POETRY OF GEOFFREY HILL: AUTHORITY AND EXEMPLARITY IN $A$ TREATISE OF CIVIL POWER

Author(s): Bridget Vincent

Source: The Modern Language Review, Vol. 110, No. 3 (July 2015), pp. 649-668

Published by: Modern Humanities Research Association

Stable URL: http://www.jstor.org/stable/10.5699/modelangrevi.110.3.0649

Accessed: 10-03-2016 18:29 UTC

\title{
REFERENCES
}

Linked references are available on JSTOR for this article:

http://www.jstor.org/stable/10.5699//modelangrevi.110.3.0649?seq=1\&cid=pdf-reference\#

references_tab_contents

You may need to log in to JSTOR to access the linked references.

Your use of the JSTOR archive indicates your acceptance of the Terms \& Conditions of Use, available at http://www.jstor.org/page/ info/about/policies/terms.jsp

JSTOR is a not-for-profit service that helps scholars, researchers, and students discover, use, and build upon a wide range of content in a trusted digital archive. We use information technology and tools to increase productivity and facilitate new forms of scholarship. For more information about JSTOR, please contact support@jstor.org. 


\section{THE EXEMPLARY POETRY OF GEOFFREY HILL: AUTHORITY AND EXEMPLARITY IN A TREATISE OF CIVIL POWER}

I believe that it is inevitable that any serious poetry written at the present time will be inextricably caught up in politics.

Poetry has no public.

(Geoffrey Hill)

Geoffrey Hill made both of the above comments within one relatively short address - a reading with commentary held at the Collège de France in March 2008. For Hill, what might look like divergent sentiments form part of a unified theory of poetry's public position, which he summarizes as follows: 'Poetry is an art of public significance while at the same time I recognize that poetry has no public. ${ }^{1}$ His conviction that a poet's autonomy and hermetic refusal to court public attention renders him or her more rather than less relevant to civic life derives from a long-standing non-consequentialist vein in his ethics, manifested most consistently in his preoccupation with 'intrinsic value'. ${ }^{2} \mathrm{Hill}$ declines to elaborate, however, on how the intrinsic might become extrinsic, on how the value inhering in literary choice eventually translates to its political correlate. It is in the context of this lacuna that his preoccupation with exemplarity - his notion of the poem-as-example-can offer a degree of interpretative purchase. The concept of exemplarity is characterized by the very tension between transitive and intransitive definition which underpins the idea of intrinsic value: just as intrinsic value has an outward effect regardless of outward acknowledgement, so too is an example defined both by its effect on its followers and by its inherent qualities. A poem can be 'exemplary' by virtue of its independent merit but also because it influences others.

Specifically, Hill sets up certain poems as model specimens or exemplars which preserve the integrity of verbal nuances-nuances which, if elided, create opportunities for deception and corruption. He presents fine linguistic distinctions (such as that between 'to dispense | with justice' and 'to dispense, with justice' from The Mystery of the Charity of Charles Péguy, where the insertion of a comma has made all the ethical difference) as though they are microcosmic rather than simply microscopic, miniature rather than simply

${ }^{1}$ Geoffrey Hill, 'A Reading and Discussion of my Own Writings in the Context of Contemporary British Philosophy and Poetry', Collège de France, Paris, 18 March 2008. Transcribed from a video recording at <http://www.college-de-france.fr/default/EN/all/act_eve/m_geoffrey_hill.htm $>$ [accessed 27 August 2009].

${ }^{2}$ For Hill's most comprehensive discussions of this concept see the essays collected as 'Inventions of Value' in his Collected Critical Writings, ed. by Kenneth Haynes (Oxford: Oxford University Press, 2008), pp. 383-49o. 
small-as though there were a macrocosmic moral sphere to which these tiny decisions correspond and on which they have a barely perceptible but cumulative influence. ${ }^{3}$ Hill's presentation of language as a small-scale encapsulation of large social and historical forces is reinforced by his use of related descriptors throughout his prose. Various cognate terms help to foreground the concept of the exemplary in his writing, including 'paradigm', 'emblem', 'embodiment', 'epitome', 'model', 'blueprint', and 'parable'. Together they gesture beyond any straightforwardly one-for-many logic of representation and towards the more idiosyncratic emphasis on concentration and condensation that characterizes his definition of exemplarity.

In an interview with John Haffenden, Hill makes this association between the poetic and the exemplary explicit: poetry, he proposes, is 'a form of responsible behaviour, not a directive. It is an exemplary exercise.' ${ }^{4}$ While this statement is often cited simply as evidence of Hill's interest in exemplarity, the argumentative context reveals the phrase to be a more complex space of negotiation, as he uses this claim to defend poetry from charges of both irresponsible autonomy and polemical over-engagement. While the argument in which he invokes the category of exemplarity offers (to a degree) a reassertion of the poet's social relevance, this exemplary relevance and 'responsibility' is located in the process of individual 'behaviour' rather than in social intervention. The contrast he stresses between 'responsible behaviour' and 'directives', in particular, highlights the exemplar's simultaneous invocation of inward and outward implication. The exemplary poem comes to have such significance for Hill, then, because it captures particularly acutely his long-felt tension between these two impulses.

This tension between autonomy and engagement is grounded in the swerves inherent in the term 'responsible' itself, which he has in the past used to denote both wider obligation and a defiant hermetism. When Carl Phillips, in his interview, asked 'What is the responsibility of the poet?', Hill gives only a Wittgensteinian shrug: 'To write the poems.' 5 However, his initial restriction of the poet's responsibility to 'writing the poems' immediately slips into something larger, as the responsibility to poems themselves becomes the responsibility to 'witnessing': 'Why should it matter that a poet has to be responsible? Everybody has to find his or her own way of witnessing, and the only way I can effectively witness is by writing.' 6

While references to exemplary poetry such as that occurring in Haffenden's

3 Hill, 'The Mystery of the Charity of Charles Péguy', in Broken Hierarchies, ed. by Kenneth Haynes (Oxford: Oxford University Press, 2013), pp. 141-53 (p. 148).

${ }^{4}$ John Haffenden, 'Interview with Geoffrey Hill', in Viewpoints: Poets in Conversation with John Haffenden (London: Faber, 1981), pp. 76-99 (p. 99).

5 Carl Phillips, 'Interview: Geoffrey Hill, The Art of Poetry LXXX', Paris Review, 154 (2000), 27299 (p. 297).

6 Ibid., p. 298. 
interview have been present throughout his career (the above conversation, for instance, took place in 1981), this concept becomes particularly important in his later collections. As Hill's sense of the dishonesty and injustice wrought by 'plutocratic anarchy' reaches a more and more despairing pitch, his grasping for a publicly significant poetics becomes increasingly urgent. 'Plutocratic anarchy', a Ruskinian term, is one of his frequently repeated names for our current moment and the commodity culture which defines it. He uses this term in conjunction with (or even interchangeably with) 'oligarchical consumerism'7 or 'business convenience' 8 as a corrective to facile descriptions of this age as straightforwardly 'secular' or 'democratic'. A particularly clear instance of this usage occurs in his 2011 Economist video interview: 'Rather [than] say "Yes yes, we are living in a secular age", I would say we are living in an age of anarchical plutocracy.' 9 In the past decade, Hill has frequently made exemplarity an explicit theme, and one to which he returns with anguished regularity. In the search to define and advocate a poetry of resistance, illustrative instances from the past (individuals and works which managed to achieve the aims he sets for himself) come to appear particularly valuable. In Hill's millennial mental climate, certain predecessors are no longer simply forebears but tutelary models-models we ignore at our peril. The process of repeated venerative references to a set series of exemplary figures, then, becomes a means through which Hill's self-definition as a particular form of public poet is reiterated and affirmed.

Some responses to Hill's earlier collections (such as Henry Hart's review of The Mystery of the Charity of Charles Péguy) made passing reference to exemplarity, but critical attention to this dimension of his work has grown in line with his own increasing preoccupation. ${ }^{10}$ As early as 1985, Peter Robinson wrote that "exemplary" is one of Hill's much loved and needed words'. ${ }^{11}$ The appearance of a Hill essay called 'The Exemplary Failure of T. H. Green'12 provided a titular template for Stephen T. Glynn, who in 1987 called an ar-

7 Hill, 'Policing and Public Order', University of Oxford, 29 November 2011. Transcribed from an audio recording at <http://media.podcasts.ox.ac.uk/kebl/general/2011-11-30_geoffrey_hill_ poetry.mp3> [accessed 2 March 2012].

8 Hill, 'A Reading'.

9 Hill, 'Interview', The Economist Online. Transcribed from a video recording at <http://www. economist.com/blogs/prospero/2011/12/economist-books-year-festival-geoffrey-hill> [accessed 10 February 2012]. Hill gives particularly detailed definitions of the term 'plutocratic anarchy' in two late pieces: Geoffrey Hill, 'Civil Polity and the Confessing State', Warwick Review, 2.2 (2008), 7-20; also Geoffrey Hill and others, 'Strongholds of the Imagination', Oxonian Review, 9.4 (2009) $<$ http://www.oxonianreview.org/wp/geoffrey-hill/> [accessed 19 September 2009].

10 Henry Hart, 'Geoffrey Hill's The Mystery of the Charity of Charles Péguy: A Commentary', Essays in Criticism, 33 (1983), 312-38.

${ }^{11}$ Peter Robinson, 'Reading Geoffrey Hill', in Geoffrey Hill: Essays on his Work, ed. by Peter Robinson (Milton Keynes: Open University Press, 1985), pp. 196-218 (p. 209).

${ }^{12}$ Hill, "Perplexed Persistence": The Exemplary Failure of T. H. Green', in Collected Critical Writings, pp. 109-26. 
ticle " "Biting Nothings to the Bone": The Exemplary Failure of Geoffrey Hill" but did not engage with the specific ramifications of the term other than to cite Hill's description of mysticism as 'an exemplary discipline'. ${ }^{13}$ However, Andrew Roberts (reflecting on critics' assimilation of writers' characteristic vocabulary) was in the same year already discerning a reiteration of this term in Hart and others' criticism of Hill. ${ }^{14}$ From the late 1990 os onwards, this attention became more widespread. In 1996 David Gervais published an article based largely on the premiss that a greater understanding of Hill's poetry might be gleaned from identifying his exemplars. ${ }^{15}$ While the article at times conflates exemplarity with a more straightforwardly imitative sense of influence which in its univocality is somewhat at odds with Hill's, his exploration of 'what makes Wordsworth a touchstone for Hill' attests to a growing attention to these questions. ${ }^{16}$

A 1997 essay by Mark Tranter entitled " Tempestuous Fantasies" of the Exemplary Figure: Geoffrey Hill's Scenes with Harlequins' presses upon the category of exemplarity in considerably more detail. ${ }^{17}$ Tranter identifies Hill's use of it as a figure for the ambiguous public position of poetry, and as a designator of ambivalent regard or 'muted admiration' for other disciplines and for other writers, such as T. H. Green: 'In some ways Green is an example for us to admire and follow, but he must also "be made an example of" for his faults. ${ }^{18}$ By 2004, Marius Kociejowski was able to describe the word as something so pervasive as a 'verbal tic' in Hill's writing. ${ }^{19}$ In 2007 Stephen James offered some of the most detailed analysis of exemplarity in Hill with his reflections on the role played by exemplarity in Hill's conceptions of authority and eccentricity. ${ }^{20}$ As recently as 2010, Christopher Ricks presented new work on Hill's identification of exemplary figures in True Friendship: Geoffrey Hill, Anthony Hecht and Robert Lowell under the Sign of Eliot and Pound. ${ }^{21}$ As is reflected in this growth of critical attention, the concept of the exemplary poem becomes increasingly important to Hill's formulation of a 'responsible' poetics (one which is neither culpably detached nor compromised by ideological com-

\footnotetext{
13 Stephen T. Glynn, "'Biting Nothings to the Bone”: The Exemplary Failure of Geoffrey Hill', English, 36.156 (1987), 235-64 (p. 246), citing Haffenden, 'Interview', p. 89.

14 Andrew Roberts, 'Hill's Example', English, 36.156 (1987), 286-91.

15 David Gervais, 'An "Exemplary Poet": Geoffrey Hill's Wordsworth', Agenda, 34.2 (1996), 88-103.

${ }^{16}$ Ibid., p. 91.

17 Mark Tranter, “"Tempestuous Fantasies” of the Exemplary Figure: Geoffrey Hill's Scenes with Harlequins', English, 46.184 (1997), 39-59.

${ }^{18}$ Ibid., p. 45.

19 Marius Kociejowski, 'CM: A Portrait', Chicago Review, 51.1/2 (2005), 80-89 (p. 83).

${ }^{20}$ Stephen James, Shades of Authority: The Poetry of Lowell, Hill and Heaney (Liverpool: Liverpool University Press, 2007)

${ }^{21}$ Christopher Ricks, True Friendship: Geoffrey Hill, Anthony Hecht and Robert Lowell under the Sign of Eliot and Pound (New Haven: Yale University Press, 2010).
} 
mitment) and helps him identify those who stand before him as imperfect but nonetheless (or therefore) tutelary models by virtue of achieving or at least approaching this balance.

Importantly, the terms 'example' and 'exemplary' also emerge in a less valueladen context as a means of describing entities which encapsulate or embody larger phenomena, both positive and negative, and so offer him not only a form of ethical shorthand but also an intellectual placeholder for a specific kind of condensed representation. By virtue of this latter capacity particularly, exemplarity not only provides a valuable lens for viewing the idiosyncrasies of Hill's late style, but also speaks to one of the more persistent critical questions surrounding his treatment of history. When a poem is thought to provide an 'example' of an ideological position, rather than simply a description of it, the writing modulates the ethical risks attending historical citation in acute and revealing ways. The poems in which Hill takes bad examples from the past open out, I will suggest, onto continuing debates about political complicity and pastiche in his various strains of archaism.

\section{Exemplary Remembrance}

Just as the twilit 'Peacock at Alderton' gathers his 'fulgent cloak', Hill, increasingly, guards against the advancing dark by gathering his own cloak of luminaries. ${ }^{22}$ His ever more frequent citation of his exemplary forebears leads, in A Treatise of Civil Power, to a unique consistency of conceit-the overwhelming majority of the collection's pieces record a same-shaped moment of aesthetic response. This is signalled by a uniformity in titling conventions: most titles begin with 'On Reading' or 'After Reading' or 'On Looking', or simply with the name of the original work. The collection's repeated focus on the aftermath of aesthetic apprehension speaks, I want to suggest, to a heightened self-consciousness about the process of interaction with the literary or political predecessor. As his description of the 'noble collusion' in Bacon (in which there is more anger than adulation) clearly attests, not all of the Treatise's engagements with other works treat earlier pieces as exemplars, and even the poems which find much to admire in the originating work or individual do not always treat the predecessor as a guide. ${ }^{23}$ It is this ambivalent moment of apprehension and the more ongoing process of negotiation it encapsulates, in which present writers self-define against (or in line with) their ancestors, which here becomes the emphasis. The collection's self-fortifying effort to identify exemplars is constantly shot through with the destabilizing process of defining what exemplary status entails.

22 Hill, 'The Peacock at Alderton', in Hierarchies, p. 587.

23 Hill, 'On Reading The Essayes or Counsels, Civill and Morall', in Hierarchies, pp. 595-96 (p. 595). 
While some of the pieces in A Treatise draw on poems or poets, the majority are based on other forms of writing (and, indeed, non-verbal forms of artistic and intellectual activity), further complicating the exemplary status of the original works. While the poems of Aleksander Wat might suggest a reasonably straightforward line of guidance, ${ }^{24}$ it is less clear how a Barlach sculpture ${ }^{25}$ or a work of revisionist historical scholarship ${ }^{26}$ or a Brahms sonata ${ }^{27}$ might act as an exemplar to a Hill poem. In a sense, however, it is this very generic difference that gives these other forms their exemplary power. In a number of the pieces based on non-verbal forms, Hill emphasizes how the structural properties inherent in the original objects allow them to work in ways less immediately available to poetry. Hill quotes, for instance, Willy Brandt's explanation of his Warsaw apology, in which the bodily gesture of kneeling expressly replaces language. Brandt acknowledges this explicitly: 'I did what people do when words fail them. ${ }^{28}$ Likewise, many of the poems in this collection can be viewed as explorations of how other forms succeed where 'words fail'. These other forms, then, are exemplars both in the sense of highlighting elements of poetic art that are more fully developed in other media, but also in pointing to what a poem might aim for but never reach.

A form of art to which the collection makes especially frequent recourse is music. Hill has paid specific attention to comparing the relative capacities of the two endeavours in what becomes an ars poetica in indirect form. In his Haffenden interview he articulates what he would like to achieve in poetry by isolating what he admires in music: musical 'signs are translated into the immediate, sensuous configurations of sound, the actual iconic presence of brazen instrument and shaken air, in a way that poetry can only envy'. ${ }^{29} \mathrm{Simi}-$ larly, in this collection he casts a piece of music (Handel's Concerti Grossi, Opus 6) as an instantiation of his own project. Just as his book is called $A$ Treatise of Civil Power, this poem discovers the same 'treatise' in moments from Handel: 'each of itself a treatise of civil power'. ${ }^{30}$

In some pieces it is not music but the physical shape or embodiedness of other art forms - their ties to gesture and manual labour-that are the source of their specific and exclusive potential. In a reflection on his great-grandfather's work as a puddler, he presents puddling as a form of imaginative labour which achieves some of the artistic goals poetry cannot. Puddling, he writes in 'Coda', is 'more an art | than is some hammered threnos'. ${ }^{31}$ This is a reflection on the

\footnotetext{
${ }^{24}$ Hill, 'In Memoriam: Aleksander Wat', in Hierarchies, p. 593.

25 Hill, 'In Memoriam: Ernst Barlach', in Hierarchies, p. 597.

${ }^{26}$ Hill, 'On Reading Milton and the English Revolution', in Hierarchies, pp. 562-64.

27 Hill, 'Johannes Brahms, Opus 2', in Hierarchies, p. 592.

${ }^{28}$ Hill, 'On Looking through 50 Jahre im Bild: Bundesrepublik Deutschland', in Hierarchies, p. 580.

29 Haffenden, 'Interview', p. 91.

${ }^{30}$ Hill, 'G. F. Handel, Opus 6', in Hierarchies, p. 585.

${ }^{31}$ Hill, 'Coda', in Hierarchies, pp. 599-600 (p. 599).
} 
aims and failings of the surrounding poem itself, as this poem is also a 'threnos' or song of lament and memorialization. The piece records, in the diction of grimly steadfast witnessing (familiar in part from his declaration in Mercian Hymns that 'I speak this in memory of my grandmother'), ${ }^{32}$ the 'Welsh ironpuddler's portion' and the mechanizing dehumanization this involved: 'his | penny a week insurance cum burial fund | cashing-in pain itself'. ${ }^{33}$ Echoing the emphatic performativity of the Mercian Hymns' memorial gesture ('I speak this'), this poem contains similar moments of self-identification which fix the words, as they are uttered, in a formal memorial tradition:

I add on oath (as prudent as you get)

that the Welsh puddler's my great grandfather,

[...].

This is as formal as a curse or cry,

the verse, I mean. ${ }^{34}$

In making specific reference to a form of writing in which the poem obviously participates (the 'threnos') and then proposing that puddling is 'more an art' than the threnos is, he identifies another way in which poets might stand to learn from practitioners of other endeavours. This turn towards the memorial in 'Coda' is characteristic, as memorialization is one of the particular processes which Hill identifies as being at times better served by other art forms than by poetry. As he has said directly, 'I'm an "in memoriam" poet', 35 and many of the models from other art forms in this collection are exemplars, specifically, of when and how to mourn. Many of the memorializing poems in A Treatise of Civil Power, then, are both attempts at memorialization and reflections on how these attempts fail, and fail in ways specific to poetry.

Hill's concern with the ethical limits of his own memorial impulses is, of course, a long-standing preoccupation, and his search for models outside verbal art also pre-dates this collection. In his analysis of visual art references in The Triumph of Love and Speech! Speech!, Michael John Kooy argues that Hill ascribes an exemplary role to pictorial representation, especially in the realm of witnessing. Kooy argues that Hill perceives, for instance, Oskar Kokoshka's portrait of Tomáš Garrigue Masaryk as 'a model of how to praise, to pay tribute'. ${ }^{36}$ It is in circumstances like these that images, according to Kooy, 'as successful public witnesses to events [...] represent the condition to which the poetry itself aspires'. ${ }^{37}$ Hill's decades-long reflection on the aims

32 Hill, 'Mercian Hymns XXV', in Hierarchies, p. 107.

33 Hill, 'Coda', p. 599.

34 Ibid.

35 Hill and others, 'Strongholds'.

${ }^{36}$ Michael John Kooy, 'Word and Image in the Later Work of Geoffrey Hill', Word and Image, 20 (2004), 191-205 (p. 197).

37 Ibid., p. 192. 
and the failings of poetic memorializing is carried forth-and considerably diversified-in A Treatise of Civil Power. 'In Framlingham Church' takes as its explicit theme the memorializing powers of different forms: their capacity to take the full measure of a life and to attempt to atone for its loss. Where he sees Surrey's tomb, for instance, failing in this task ('Surrey's ornate, unsatisfactory tomb, | not to the life at any rate, stiff | inaccurate pietas seventy years delayed'), he finds a countervailing adequacy in a Holbein sketch: 'nothing atones ever, but for a moment, | Holbein's unfinished sketch perhaps'..$^{38}$

One of the collection's most thoroughgoing reflections on the ways in which different forms inflect memorialization appears in 'On Looking through 50 Jahre im Bild: Bundesrepublik Deutschland'. Hill has explicitly stated that 'the point of the poem is in the final line'39-the line which repeats the explanation Willy Brandt gave for falling to his knees instead of speaking before the Warsaw Ghetto memorial: 'I did what people do when words fail them'. ${ }^{40}$ Ultimately, this poem is a reflection on how pictorial forms of remembrance might fare better than words but also fall short in their own ways. The poem, like 'Coda', is itself something of a memorializing project. Early in the poem is a list of people and categories of people. The list could refer to those who came after the period being memorialized or those who were lost: 'hirelings, the resourceful; | those who are obese-the excellent heads of hair- | the beautiful or plain wives, secretaries and translators'. ${ }^{41}$ Such enumeration constitutes a humane and democratic gesture of universal respect in that it remembers all people and commingles negative or neutral characteristics alongside positive ones in pointing out groups - 'those who are obese', and 'the beautiful or plain wives'. This gesture is complicated, however, by a reductive element in the denotation of the individuals, as they are defined in relation to their employment ('hirelings, the resourceful', 'secretaries and translators') or through a dehumanizing synecdoche which substitutes the whole individual for a specific part of their person ('the excellent heads of hair'). Before this ambivalence is even encountered, however, the opening lines hint at the ultimate impossibility of attempts at retrospective justice: an impossibility both for the poem and for the 'coffee-table book' of photographs on which it reflects: 'It is not a matter of justice. Justice is in another world. | Or of injustice even; that is beside the point, or almost. ${ }^{32}$

The poem highlights the dislocation between the book's photographic representations and the possibility of bringing justice by describing the pictured

${ }^{38}$ Hill, 'In Framlingham Church', in Hierarchies, p. 577.

39 Hill, 'A Reading'.

${ }^{40}$ Hill, '5o Jahre', p. 580.

${ }^{41}$ Ibid.

42 Ibid. 
historical scenes in the language of theatrical display, with all its attendant connotations of ephemerality and insignificance:

The riots and demonstrations that now appear

like interludes, masques, or pageants, or students' rags;

the police water-cannon: you look for the film's director

but cannot find him.

The deictic 'now' situates this bathetic revisioning in a moment both recorded and repeated by the poem. It is in the 'now' of 'looking through' (with all the connotations of brief attention and disengaged leafing this carries) this glossily commodifying testimony that these demonstrations appear no longer as scenes of organic struggle. ${ }^{43}$ They are the vision of 'the film's director', a deus absconditus the belated reader 'cannot find'. In the aftermath of the book's pictorial packaging of history, the landmarks of the city become objects of a reframing gaze which superficially renovates rather than genuinely atones: the Berlin Wall is the 'captioned Wall' and the Brandenburger Tor is 'variously refurbished'. ${ }^{44}$ The poem, then, looks to visual forms of memorialization, finding a possible exemplar in Brandt's gesture, and at the same time looks through and beyond them, in the sense of acknowledging that they carry their own ethical risks and limits.

While the visual forms of remembrance acknowledged in A Treatise of Civil Power are shown to be fraught with their own compromises, they are consistently treated as, if not ideal, nonetheless salutary models of memorialization which encapsulate those effects that Hill would like to achieve in poetry but perceives as more possible or likely in other forms. By dwelling on the alternatives to language he sheds light on how and why verbal art falls short when poets-including himself-attempt to remember and atone.

\section{Demonstrative Hill}

Hill's late work concentrates more and more specific attention on the ways in which poetry might exert exemplary influence not only over other poets but also over the polis. Despite stringent awareness of the limitations inherent in his own form, Hill explores with guarded but persistent hope the potential for stubbornly inward poetry to hold, as intrinsic value holds, wider civic implications. Accordingly, his late poetry is increasingly punctuated by moments in which the speaker's voice self-consciously identifies as an exemplar. The voice acts, that is, as the demonstration or embodiment (rather than

43 Susan Stewart uses this phrase as a chapter title-'The Deictic Now'-in her Poetry and the Fate of the Senses (Chicago: University of Chicago Press, 2002).

44 Hill, '5o Jahre', p. 580. 
discursive articulation) of the social, intersubjective, compositional, or civic concerns raised in the surrounding work.

The specific status of these lines as exemplars of ideas about poetry, rather than simply as discussions, is in part the product of an increasingly pervasive self-reflexive tropism in the later collections. This self-reflexive dimension has been present in his poetry from very early on, as Roberts's 1987 review attests, ${ }^{45}$ but it takes a particularly uniform shape in A Treatise. ${ }^{46}$ Such directly self-referential language is visible in 'Nachwort', which describes the 'wrench' involved in making the very lines the reader encounters-'I shall wrench out of this'. In this poem, attention is fixed in both space and time with a deictic 'this' and 'now'. ${ }^{7}$ 'To the Lord Protector Cromwell' contains similarly self-reflexive moments, referring, in a highly allusive poem and collection, to 'this hire-house of ceaseless allusion'. ${ }^{4}$ Similarly, in the phrase 'if I may so construe it', the 'so' refers to the real-time process of the line's construal of sense. ${ }^{49}$

One of the most baroque moments of Hill's compositional self-analysis occurs in 'On Reading Milton and the English Revolution':

Debridement that means reaming out the mock

virginity of the wound. Idiolect

that could be idiot dialect but isn't, wrinching and spraining the text for clown-comedy amid the pain, the inward and irremediable disposition of man-this I can live with. ${ }^{50}$

Here Hill, citing Milton's line from 'Of Reformation Touching ChurchDiscipline in England', ${ }^{51}$ suggests that he himself is creating 'clown-comedy' by 'wrinching and spraining the text'. This refers particularly closely to his practices in the present stanza, as when this line is uttered, he has just finished 'spraining' the words 'debridement' and 'idiolect': turning the words inside out etymologically to explore the interactions between their accepted meanings and literal connotations. ${ }^{52}$ He sets the surgical meaning of debridement (wound-cleaning) against the literal meanings which emerge when the word is broken into its constituent components: debridement becomes de-bridement,

45 Roberts, p. 286.

46 This dimension is also present in collections published after A Treatise, but as exemplarity and self-reflexivity manifest themselves slightly differently and on a larger scale in 'The Daybooks', these collections lie outside the scope of this discussion.

47 Hill, 'Nachwort', in Hierarchies, p. 601.

${ }^{48}$ Hill, 'To the Lord Protector Cromwell', in Hierarchies, pp. 571-74 (p. 574).

49 Ibid., p. 574.

$5^{\circ}$ Hill, 'On Reading Milton and the English Revolution', in Hierarchies, pp. 562-64 (p. 563).

51 John Milton, Of Reformation Touching Church-Discipline in England (London, 1641), p. 65.

52 For a detailed and illuminating reading of this passage in the context of a discussion of Hill's preoccupation with philology and the fallen nature of language, see Matthew Sperling, Visionary Philology: Geoffrey Hill and the Study of Words (Oxford: Oxford University Press, 2014). 
which is especially resonant given the subsequent line's allusion to virginity. This allusion echoes further in the fourth and fifth lines of the stanza, as they cite Milton's treatise on The Doctrine and Discipline of Divorce. ${ }^{53}$ In an additional stroke of the 'clown-comedy' found in exploring semantic roads-not-taken, he expands 'idiolect' to discover 'idiot dialect', which he sits impishly against the technical overtones of its actual meaning-a personally individuated dialect.

In this poem the function of the text as an exemplar of the processes it describes (he is 'spraining' language just as he alludes to the prelates whom Milton condemns for 'spraining the text') is layered with the whole collection's undertone of concern with the exemplary status of those who judge as well as those who create. 'Intrinsic value', for Hill, is maintained not only by practitioners but also by figures of authority who adjudicate over their praxis. Hill's anxieties about the unexemplary conduct of exemplary poets is reflected in his concerns, echoing Milton's, about the corruption of those in positions of juridical power, whether this power be civic, aesthetic, or spiritual. This poem's emphasis on intermediary authorities stresses their ultimate fallibility. This emphasis emerges particularly clearly through his reference to 'radiant urim'. ${ }^{54}$ As Tim Kendall observes, the 'radiant urim' were the stones which distinguished those who mediate between higher powers and the earthly world according to the thought of Robert Fludd, to which, as Kendall notes, Milton makes reference in Book VI of Paradise Lost. ${ }^{55}$ Milton's reference to 'wrinching and spraining' cited in the present stanza is uttered in the context of his lamentation on the decay of prelates. Given that Milton sees this decay as being effected through a decline in textual integrity, the poem raises further glancing questions about the possibility of dubious complicity in Hill's own 'spraining' of the lines. ${ }^{56}$

The status of these self-reflexive moments as examples of the ideas advanced in the poem (something more idiosyncratic than generalized deictic self-referentiality) becomes especially clear in cases where a poem's exemplary gesture is framed by a theoretical introduction. This framing theory comes in either imperative or descriptive form, and has the effect of casting the subsequent lines as its illustrative embodiment. The descriptive passage in 'The Peacock at Alderton', for instance, has the following preamble: 'I will attempt | to describe them, as if for evidence | on which a life depends. ${ }^{57}$

53 Milton, The Doctrine and Discipline of Divorce Restor'd to the Good of Both Sexes from the Bondage of Canon Law and Other Mistakes to Christian Freedom, Guided by the Rule of Charity: Wherein Also Many Places of Scripture Have Recover'd their Long-Lost Meaning. Seasonable to be Now Thought on in the Reformation Intended (London, 1643), p. 44.

54 Hill, 'On Reading Milton', p. 562.

55 Tim Kendall, 'Hire Houses', TLS, 12 October 2007, pp. 24-25.

${ }_{56}$ Milton, Of Reformation, p. 65.

57 Hill, 'Peacock', p. 587. 
With such a frame, the subsequent lines come to read as an example of what it means to describe in such a juridically weighted fashion. It could be argued that description is an especially non-exemplary mode of utterance in that it is a mode which potentially reaches towards transparent communication. However, the peculiar status of these lines as the exemplification of description might be considered to annul the transparency associated with description itself. Every detail of the feather is recounted with forensic attentiveness: the two elements (the threads and the eyes) are considered separately; great care is taken in specifying the exact shade of each colour; and an abundant variety of metaphorical connotations are pressed from the image of the eyes-they are 'like a Greek letter, | omega, fossilised in an Indian shawl; like a shaved cross-section of living tissue'. There is an element of synaesthesia, also, involved in describing the peacock as 'display[ing] his scream', which speaks to the current of interartistic imitation running throughout the collection. Just as the 'fulgent cloak' is part of his mating display, here so too is the noise he makes. The connections between the 'scream' and 'display' raise further questions about the dimensions of public display involved in his poetry's call of despair.

The demonstrative charge of some of these self-reflexive moments is redoubled by their inclusion of imperatives. Given that these are orders about poetry, Hill's own lines read as manifestations of his own recommendations. Several imperative moments in which Hill seems to be giving instructions to himself as well as to his putative addressee appear in 'To the Lord Protector Cromwell': 'use | any commonplace book as model: strings | of synonyms, cramped maxims, anecdotes'. Similarly, the exhortation to ' $[\mathrm{k}]$ eep to this strong voice | like Milton's sonnet with its signal purpose; | your known affect for Jewry and for music' speaks directly both to the figure of Cromwell and to the 'strong voice' of the order-riddled poem. ${ }^{5}{ }^{8}$ These lines allude especially mordantly to Hill's own writing given that they pick up on the cardinal clichés surrounding his reception: the conflicting responses to his memorialization of the Shoah ('affect' can suggest not only emotional response but also affectation); and the element of 'strength' in his verse, a much-cited dustjacket descriptor.

In the background to these exemplary moments' fusion of description and participation-of the order and its fulfilment, the instruction and its tutelary exemplar-is Hill's ongoing interest in performativity. Sometimes performative language is in the foreground rather than the background, as is the case in his use of such classically Austinian statements as 'I ordain', in 'On Reading Milton and the English Revolution'. ${ }^{59}$ Hill's preoccupation with

58 Hill, 'Cromwell', p. 571.

59 Hill, 'On Reading Milton', p. 563. 
performativity, and with expanding Austin's definitions to include artistic language, dates back to the seminal 'Our Word is Our Bond'. ${ }^{60}$ What is significant about this heritage in the present context, however, is that questions surrounding performativity constitute a (slant and incomplete) condensation of his larger social concerns. His ongoing engagements with the capacity of the written word as a form of public act are crystallized in performative theory's connection between uttering and doing. Hill displays characteristically self-qualifying caveats in his hopes for the ultimate effectiveness of this form of poetic intervention, however. As his comments on Pound illustrate, doing-through-saying has the status of a desire: 'Modern poetry, we may suggest, yearns for this sense of identity between saying and doing [...] but to Pound's embarrassment and ours it discovers itself to possess no equivalent for "hereby".'61

The isomorphism between Hill's interest in performativity and in the poem as social act is further complicated and triangulated by his engagement with the dynamic between the performative and performance. Many of his later poems which concern themselves with civic participation use conceits related to theatricality: this is most obvious in Scenes from Comus but also evident throughout A Treatise of Civil Power, with its recounting in 'After Reading Children of Albion (1969)' of a performer who re-enacted Kemp's Jig, ${ }^{62}$ its references to clowns (carrying further complicating resonances of their own), ${ }^{63}$ and its forays into the world of Jacobean masques. ${ }^{64}$

Through its preponderance of imperative diction, Hill creates for himself in one of the collection's longest poems, 'A Précis or Memorandum of Civil Power', a particularly potent opportunity to present his lines as exemplars of the poem's guiding ideas. From the exhortation to 'come round to the idea' in the poem's beginning lines to its departing injunction to 'make do with cogent if austere finale', the poem progresses in large part by issuing instructions, as the administrative cast of its title implies. ${ }^{65}$ These instructions, if they could be called anything so unreservedly confident, concern the status of 'civil power' and the lies, betrayal, and corruption which corrode it. In tune with the poem's self-inculpatory hesitations about the word's collusion with 'worldly' forces, however, he also uses fragments of his language as a form of cautionary example: in his own play of treacherous cliché, he demonstrates the very deceptions and evasions against which he is warning.

The culpability of 'civil power' in this poem is frequently associated with the

${ }^{60}$ Hill, 'Our Word is Our Bond', in Collected Critical Writings, pp. 146-69 (p. 146).

61 Ibid., p. 163.

${ }^{62}$ Hill, 'After Reading Children of Albion (1969)', in Hierarchies, p. 578.

${ }^{63}$ Hill, 'On Reading Milton', p. 563.

${ }^{64}$ Hill, 'Masques', in Hierarchies, p. 567.

65 Hill, 'A Précis or Memorandum of Civil Power', in Hierarchies, pp. 581-84 (p. 584). 
dishonesty and betrayal made possible by linguistic deception. For instance, public apology in its prevailing diluted form comes under particular fire: 'Civil power now smuggles more retractions | than hitherto; | public apology ad libs its charter. ' ${ }^{\prime 6}$ Here the deceit suggested by 'smuggles' is based in the linguistic action of 'retraction', and the integrity of the 'charter' is broken through the spoken gesture of the 'ad lib'. Conversely, the countervailing movements towards justice which the stanza lists immediately afterwards are all based on verbal forms of intervention: 'The statute books $\mid$ suffer us here and there to lift a voice, | judge calls prosecutor to brief account, | [...] | Letters to the editor can show wisdom.' In locating in language both the origins and the potential remedies of the prevailing corruption, this stanza raises a concern which runs through the whole poem about how an art form can avoid collusion when it works in the same medium as the phenomena it seeks to undermine. Whether Hill's acknowledgement of the moral corruption risked in writing guards against non-verbal ethical hazards remains an open question. Might, that is, the principles of intransigence and intricate attention which guide Hill's verbal ethics be sound when applied to words but potentially unsound when applied to people?

This poem's questioning of the relationship between 'Civil Power' and the poet's utterance begins with the wording of the title. With its ambiguously attributive 'of', combined with its bureaucratic connotations of 'memorandum' and the pragmatic efficiency of 'précis' (these stand out particularly noticeably by virtue of being the variants from the collection's title and its Miltonic precedent), it could easily issue from the world at which it is directed. The participation of individuals in 'power'-the monolithic agent (positioned as the acting subject in phrases like 'civil power now smuggles') - is echoed in the recognition that 'we make history; it's not some | abysmal power' ${ }^{67}$ In order to explore how this 'we' who 'make history' (and break it) includes the poet, I want to suggest that in this poem, perhaps more than any other in the collection, Hill employs a peculiarly ostensive form of self-reflexivity in which he holds his lines out as demonstrative objects or examples-examples of both salutary intervention and its eventual compromises.

As was the case in the poems discussed earlier, Hill's particular form of exemplary diction here is made possible by a degree of self-referentiality established at the outset. The opening lines describe the poem itself as 'this challenge', and this direct pointing is reiterated in the later reference to 'this chant', and (more impersonally) to 'this' in the second stanza-'How awkward this must sound'. His own lines receive the same direct attention: 'a line or two delivered without pathos'. ${ }^{68}$ The following lines are demonstrations rather

\footnotetext{
66 Ibid., p. 583.

67 Ibid., p. 582 .

68 Ibid.
} 
than simply orders in that they show what the 'unyield[ing]' 'spare strophe' they describe might look like:

Come round to the idea, even so

belated, and knock. Echo the answer

in spare strophes that yield almost nothing

to the knowledge

outside them raw with late wisdom. ${ }^{69}$

His language in the whole poem is 'spare' in that the allusions are characteristically underelaborated, and they are pared down to become even more elliptical by the removal of key conjunctions. Their lack renders the status of 'raw with late wisdom', for instance, ambiguous-it could refer either to the 'knowledge | outside' or to the 'strophes' themselves. Just as the poem itself as a whole obliquely advocates resistance to accessibility, these lines are suitably hermetic and 'yield almost nothing'. Like these introductory lines, the final line of the poem instantiates the order it issues: 'Make do with cogent if austere finale'. $7^{\circ}$ With its clarity and urgency, the phrase is an exemplar of the cogency it advocates, and its austerity, already achieved by the taut constriction of the sentence to one line (strikingly regular against the irregular beauties' of the previous line's metre), is sealed by its shorthand-like excision of the final article.

The most striking moment at which the lines exemplify their own exhortations occurs at the end of the sixth stanza:

an exultation in one's negative

powers. I aim to cite correctly but admit licence when the words won't match with my own brief

to set this tricky artefact on line

for the realm of primal justice and accord. ${ }^{71}$

'I aim to cite correctly but admit licence' reads as a statement of personal policy, offering the theory of a practice which he has just exemplified by eliding some of Marcel's original words while italicizing the line as though it were an exact direct quotation. ${ }^{72}$ The mention of 'my own brief', similarly, casts the poem as the acting out of a juridically inflected theoretical plan. This quoted moment instantiates Hill's will to 'cite correctly' but also his willingness to 'admit licence': it shows him taking the liberty of inserting his own words when Marcel's originals 'won't match'. The force of this admission was particularly strong before the poem was revised for Broken Hierarchies,

69 Ibid., p. 581.

70 Ibid., p. 584.

${ }^{71}$ Ibid.

${ }^{2}$ Gabriel Marcel, Being and Having, trans. by Katharine Farrer (Westminster: Dacre Press, 1949), p. 232. 
as previous versions placed square brackets around the words inserted into Marcel's phrase ('an exultation [in one's] negative | powers'), making this sense of editorial scruple grammatically explicit. ${ }^{73}$

What these lines both articulate and instantiate, particularly in their earlier form, is honesty manifested in the admission of dishonesty. This is not the truthfulness of avoiding the deceit involved in 'licence', but the truthfulness of owning up to licence already committed. A similarly explicit admission of guilt occurs in 'On Reading Blake: Prophet Against Empire', in which he takes a line from Whitman and then immediately owns up to it in response to an imagined 'stickler' of an interlocutor: 'contain multitudes (I've | cribbed Whitman, you stickler-short of a phrase)'.$^{74}$ In presenting the admission of deception as a form of honesty, these lines speak to the poem's larger suggestion that perfect honesty is an impossible and even culpably hubristic goal, and that what is needed instead is an ethical framework for dealing with inevitable departures and slippages. This is reflected in his ongoing emphasis on maintaining sound mechanisms for public apology (as explored extensively in the trope of the 'confessing state' in his late prose ${ }^{75}$ and in poems such as '50 Jahre im Bild'). ${ }^{76}$ 'You stickler' is an especially resonant phrase because it places these meditations on honest dishonesty in the context of the writer's interchange with imagined critics, and involves one of Hill's most cherished compositional and ethical values: to be a 'stickler' is to attend closely to detail. Here, attentiveness is wryly recast as negative rather than positive and is attributed to the reader rather than the poet. The irony of the phrase is that this 'stickler' is unlikely to exist outside Hill's mind: his critics are much less likely to be concerned by the possibility of this scrupulous figure misappropriating another writer than they are by what might be seen as circular hand-wringing about the scruple itself.

It is in this context-this preoccupation with linguistic fallibilities and the deceptions in the public sphere to which they give rise-that Hill deploys fragments of his own language as cautionary examples. This involves a process to which he has repeatedly returned throughout his career: engagement with the clichés that erode public discourse. In his criticism he has admired others, such as Jonson, Marvell, and here Gabriel Marcel (who has written that 'words get tired and worn out just as men do'), ${ }^{77}$ who have attempted to 'rinse clean' the language. ${ }^{78}$ Increasingly, his own poetry (most obviously

73 Hill, 'A Précis or Memorandum of Civil Power', Poetry, 188 (2006), 113-17 (p. 116).

74 Hill, 'On Reading Blake: Prophet against Empire', in Hierarchies, pp. 569-70 (p. 569).

75 Hill, 'Civil Polity', pp. 7-20.

${ }^{76}$ Hill, '5o Jahre', p. 580.

77 Gabriel Marcel, Tragic Wisdom and Beyond, trans. by Peter McCormick and Stephen Jolin (Evanston, IL: Northwestern University Press, 1980), p. 199.

${ }^{78}$ Hill, “"The World's Proportion": Jonson's Dramatic Poetry in Sejanus and Cataline', in Collected Critical Writings, pp. 41-56 (p. 48). 
Speech! Speech! but also The Triumph of Love) has embedded fragments of hackneyed language in order to scrutinize it and bring it to poetic justice. This poem, this embedding, has a slightly different tenor: Hill is deploying clichés in a poem which is primarily about the civic wrongs that arise from linguistic corruption, and so they take on the particular function of the exemplary instance or object lesson. Several of these clichés stand out particularly forcefully as they come mingled together and produce a moment of garbled banality: 'all interest $\mid$ set on the bias, accrued poverty | breaking every bank'. ${ }^{79}$ This collection is particularly piquant given that the references to money carry echoes of intrinsic value and its corrosion. Similar commingling occurs in his raised-eyebrow discussion of Marcel, in which academic jargon meets ironic marvelling: 'according to his lights which are quite something. ${ }^{80}$ Two further emphatic terms act as instances of the treacherous multivalence of colloquial language. He uses the word 'eminently' in a moment of grimly ironic condemnation: 'a telling run of worldly luck | eminently worthy of these maimed lives' ${ }^{81}$ In this context, the divergent charges of the word-sarcastic emphasis sits alongside connotations of renown (of which Hill is usually very wary)exemplify how 'eminence', and all the corruptions of a worldly value system it suggests, lurks within the word's more obvious denotation of emphasis. Similarly, the lines 'which passes | as verity | in veritable suffusion' play literally on the notion of untruth inside truth or 'verity' - to 'pass as verity' is to seem true without actually being so. ${ }^{82}$ This exemplification is heightened in the lines' visual juxtapositions:

as verity

which passes

in veritable suffusion.

Here 'veritable', which at once explicitly denotes exact truth but also carries an emphatic meaning with colloquial overtones of similitude but not exactitude (like 'literally'), is set against (emphasized by the spatial alignment) 'verity' to exemplify the proximity of the 'veritable' to that which merely 'passes as verity'. Given the potential for verbal art to connive in the forces it deplores, to which the foregoing readings attest, it is little wonder that Hill spends much of the rest of the collection turning to other art forms as manifestations of what a less compromised form of aesthetic resistance might look like.

One of the unresolved questions raised by Hill's deliberate exemplification of linguistic failure is whether such failure is ultimately genuine, in that the definition of failure suggests an attempt in good faith followed by a shortfall.

79 Hill, 'Précis', p. 581.

80 Ibid.

81 Ibid.

82 Ibid. 
If part of what is at stake is the uncontrollability of linguistic slippage, then it might be considered oxymoronic to have control over one's failure with words. ${ }^{83}$ Hill's comments in his 2011 Economist interview are particularly relevant to this problem: he affirms that many of his poems are about 'failing to get something or failing to be able to clear one's meaning finally', and that this evocation of failure is not incompatible with larger aesthetic success: 'I think that's a perfectly legitimate area to write in, provided one is technically efficient and ends up with something beautiful'. ${ }^{84}$ These comments attest to what might be seen as a questionably clean separation between linguistic failure understood as a thematic concern and failure or success in a poem's aesthetic goals.

\section{Exemplary Limits}

In coming off worse in his own interartistic comparison, Hill ultimately participates in his broader tendency to treat poetic self-abnegation as an indirect process of self-fortification. Indeed, in his exemplary aesthetics, he includes in the category of the 'exemplary' much that is neither admirable nor emulable. The 'exemplary' consists not only of the guiding instance but also of the instance tout court-a process of conceptual distillation in which the concepts concerned need not be positive. Unlike an ideal, the less transitive form of exemplar does not invite emulation, but rather, in throwing particular ideas and values into relief, functions as a heuristic tool. In an early review entitled 'Lives of the Poets', assessing John Haffenden's The Life of John Berryman and Eileen Simpson's Poets in their Youth: A Memoir, he writes: 'each figure is, in a negative as well as in a positive sense, an exemplary figure. Berryman's poems, like Lowell's, are compounded of, and with, forces and pressures in contemporary society. ${ }^{\prime} 5$ Lowell and Berryman are exemplary not because they provide positive role models, but because they offer a point of prism-like condensation in which certain social phenomena are 'compounded'. Being exemplars 'in a negative as well as in a positive sense', they offer object lessons rather than votives for veneration. These poets, then, are 'exemplary' because they help bring to light a particular societal phenomenon- not because they show the way out of it, but because they help to make it visible and give its opponents something solid to strike.

By virtue of Hill's inclusion under the definition of 'exemplar' those examples which simply embody the given concept (be it positive or negative), the idea of exemplarity speaks to one of the more long-standing debates

${ }^{83}$ This oxymoronic interplay is discussed in detail by Andrew Michael Roberts, 'Error and Mistakes in Poetry: Geoffrey Hill and Tom Raworth', English, 56.216 (2007), 339-61.

${ }^{84}$ Hill, 'Interview', The Economist Online.

85 Hill, 'Lives of the Poets', Essays in Criticism, 34 (1984), 262-69 (p. 263). 
surrounding Hill's ethical liabilities. Like such controversial works as 'An Apology for the Revival of Christian Architecture in England', ${ }^{86}$ 'Ovid in the Third Reich', ${ }^{87}$ and 'Funeral Music', ${ }^{88}$ certain of Hill's exemplars bring to life morally questionable or even repugnant acts and individuals. In response to the suggestion that Hill carries out a kind of citational harvesting which cannot avoid culpable complicity with the values and events it describes (and to Tom Paulin's suggestion that he presents a dubious nostalgia for a hierarchically religious social order), Hill has consistently reasserted the possibility of a diagnostic rather than participatory handling of hazardous ideological substances: 'we have got to get away from the supposition that if such emotions and experience as nostalgia and loss are the subject of a poem, or a sequence of poems, they must inevitably and necessarily be the nostalgia and loss of the poet himself'. ${ }^{89}$ Since Paulin's original attack on Hill, present-day iterations of these questions have become infrequent. This is not so much because criticism of Hill has abated or become more straightforwardly celebratory, but because his emerging late style (or styles) has thrown up additional critical questions. ${ }^{90}$ One of the problems surrounding Hill's use of history which does persist, as Roberts observed (albeit at the turn of the century), is a lack of definition surrounding critics' use of the term 'pastiche' in their descriptions of his citational gestures. ${ }^{91}$ As emerges from Roberts's reflections, the attribution of critical or complicit energies to exercises in pastiche often turns on the perceived status of mimesis and mimicry. As a form which has similitude as its central logic, the exemplar, especially in its clarificatory or embodying mode, manifests in uniquely revealing ways this dual potential for endorsement and critique. This is in part due to the vexed relationship between an exemplar and the concept it represents, as, by definition, an exemplar both is and is not a participant in its defining category. It is by nature a representative 'example', but this very representative status means that it is no longer a normal member of its group. It is this aura of exceptionalism which seems to be what allows Hill to trust, tentatively, in the separation of an exemplary figure from its surrounding mould and to defend the salutary lessons which might flow from such safely denatured citation.

\footnotetext{
${ }^{86}$ Hill, 'An Apology for the Revival of Christian Architecture in England', in Hierarchies, pp. $125-31$.

87 Hill, 'Ovid in the Third Reich', in Hierarchies, p. 39.

${ }^{88}$ Hill, 'Funeral Music', in Hierarchies, pp. 47-54.

89 Blake Morrison, 'Interview with Geoffrey Hill', New Statesman, 8 February 1980, pp. 212-14 (p. 213).

90 Ben Hutchinson offers useful reflections on the preponderance of late style as a recent focus for analysis of Hill: Ben Hutchinson, "Raw with late wisdom": Geoffrey Hill's A Treatise of Civil Power', MLR, 104 (2009), 947-61.

${ }_{91}$ Andrew Michael Roberts, 'Geoffrey Hill and Pastiche: "An Apology for the Revival of Christian Architecture in England" and The Mystery of the Charity of Charles Péguy', Yale Journal of Criticism, 13 (2000), 153-66 (p. 153).
} 
Hill's tendency to sample from the writers he holds up as examples (positive and negative) provides illustrative instances of this uneasy mimicry. In pieces such as 'On Reading The Essayes or Counsels, Civill and Morall', he inserts wholesale, for the purpose of challenging them, fragments from the original writer's work: 'So many had, and have, nothing; and Bacon | speaks of privateness and retiring. '92 While his bitter feelings about Bacon are clear here, in such moments of sampling, the almost-identity of the exemplary instance to the entity or phenomenon being cited and critiqued renders Hill's trust in the insulations of irony particularly acute.

Hill's references to historical atrocity and its linguistic residue have been excused by certain critics on the grounds that his self-consciousness confers upon him adequate distance from the original phenomena. ${ }^{93}$ His presentation of examples, in which a recapitulation, by definition, participates (on some level) in the original phenomenon, offers a particularly potent test case for such accusations and acquittals. As examples of phenomena critiqued rather than observations or descriptions of it, they display his citational impulses in ways that take anxieties about similitude and the inoculations of selfawareness to their logical conclusions. Reading Hill's work in the light of his exemplary poesis thus not only sheds new light on the shaping of his fraught civic voice and its defining negotiation between autonomy and engagement: it also speaks to some of the more intractable critical controversies surrounding his reception.

Clare Hall, Cambridge

BRIDGET VINCENT

$9^{2}$ Hill, 'Essayes', p. 596.

93 Antony Rowland, Holocaust Poetry: Awkward Poetics in the Work of Sylvia Plath, Geoffrey Hill, Tony Harrison and Ted Hughes (Edinburgh: Edinburgh University Press, 2005), pp. 63-81. 